SICK TO DEBT 
This page intentionally left blank 


\section{SICK TO}

\section{DEBT How Smarter Markets Lead to Better Care}

Peter A. Ubel, MD 
Published with assistance from the foundation established in memory of James Wesley Cooper of the Class of 1865 , Yale College.

Copyright (C) 2019 by Peter A. Ubel.

All rights reserved.

This book may not be reproduced, in whole or in part, including illustrations, in any form (beyond that copying permitted by Sections IO7 and 108 of the U.S. Copyright Law and except by reviewers for the public press), without written permission from the publishers.

Yale University Press books may be purchased in quantity for educational, business, or promotional use. For information, please e-mail sales.press@yale.edu (U.S. office) or sales@yaleup.co.uk (U.K. office).

Set in Galliard type by IDS Infotech Ltd., Chandigarh, India. Printed in the United States of America.

Library of Congress Control Number: 2019934886

ISBN 978-0-300-23846-4 (hardcover : alk. paper)

A catalogue record for this book is available from the British Library.

This paper meets the requirements of ANSI/NISO Z Z9.48-1992

(Permanence of Paper).

IO 98765432 I 